University for Business and Technology in Kosovo

UBT Knowledge Center

UBT International Conference

2015 UBT International Conference

Nov 7th, 9:00 AM - 5:00 PM

\title{
The issue of minorities in the Balkans
}

Ilir Zylfiu

University for Business and Technology, zylfiu_i@hotmail.com

Follow this and additional works at: https://knowledgecenter.ubt-uni.net/conference

Part of the Political Science Commons

\section{Recommended Citation}

Zylfiu, llir, "The issue of minorities in the Balkans" (2015). UBT International Conference. 12.

https://knowledgecenter.ubt-uni.net/conference/2015/all-events/12

This Event is brought to you for free and open access by the Publication and Journals at UBT Knowledge Center. It has been accepted for inclusion in UBT International Conference by an authorized administrator of UBT Knowledge Center. For more information, please contact knowledge.center@ubt-uni.net. 


\title{
The issue of minorities in the Balkans
}

\author{
Ilir Zylfiu ${ }^{1}$ \\ ${ }^{1}$ UBT, Faculty of Political Science, Prishtina, Kosovo \\ zylfiu_i@hotmail.com
}

\begin{abstract}
The problem of the protection of minorities was raised as an issue in the Treaty of Versailles, completed at the end of the war by the major Allied powers. The Allies had imposed certain obligations on the treatment of minorities to such states that had them in their territories. They also forecasted a trusted international organization with universal character, the League of Nations, the mission to ensure the protection of European minorities. Since the fall of the Berlin Wall and communist regimes, Europe was a witness nationalism outbreak. Whole regions were covered with ethnic conflicts which were a serious threat to the stability and unity of Europe. Today, each in its field of responsibility, the OSCE, the Council of Europe, the European Union, are coordinating their efforts to develop a coherent system for the protection of national minorities. So, protection of minorities is an important factor for the stability and unity of Europe. Western Balkan aspirant countries are a multi-ethnic society. The latest international analy ses on guide us to the fact that some Western Balkan countries aspiring of becoming EU members, judging by the EC progress, lag in the implementation of the part of the Copenhagen political criteria that deals with respecting of minority rights. As it is well-known human rights and minorities remain an objective of the European Union in its foreign policy. European Union at the beginning of XXI century has been committed with multiple projects to stability and economic development in cooperation between the countries of the region. In the study, "Minority Rights in the Eastern Balkans", 2008 made for the needs of the European Parliament, in the case of Serbia, $12,5 \%$ are presented as non-Serb population, but not the percentage of the Albanian minority in due to the lack of data. Therefore, a study on the Albanian national minority in Serbia it is more than necessary. The purpose of this paper is to present the issue to minorities in the Balkans in the historic plane. In this paper will be presented to political positions, economic, educational and minorities in general in the Balkans. It will become a comparative analy sis between the position of minorities in different historical periods and in different regimes. International agreements will be analy zed dealing with the Balkan states and peoples, respectively, will address the issue of protection of minorities in these agreements. The results from this research will contribute to shed light on the protection of minorities in the Balkan level. The research was conducted analy sis methods and relevant materials.
\end{abstract}

Keywords: minority, the constitution, the law on minorities, the education law

\section{Introduction}

Regardless of how the states have been created, few are those which can be considered as homogeneous states. In general, states face with internal diversity, such as language, race, religion, etc. For countries that rely on ethnic nationalism, their facing is with ethnic or national minorities. Facing with ethnic minorities is a very complex issue, not only to the state itself but also to the international community. Given the historical analysis, we can consider that the minorities issue has become a cause of conflict, both within the state as well as that of interstate. The causes of these conflicts lie in the fact that minority groups make efforts to maintain their identity on one hand, and of the state claiming to preserve the ethnic compactness. Minorities were and can be a cause of interstate conflicts, which come as a result of territorial claims of states to each other. ${ }^{1}$

French Bourgeois Revolution in the Balkans region had a direct influence on the nationalist awakening in XVIII-XIX centuries. Ethnic and national groups within the multinational empire began to seek the respect for national rights. The process began in the XVIII century with the request to enjoy the right of education in their mother tongue. 
The Austro-Hungarian Empire in the second half of the XIX had become a place where the minorities' issue was problematic. After the compromise of 1867, the Austro-Hungarian Empire was divided into western or Austrian and eastern or Hungarian. In both parts there was not a majority number. Both parts developed different policies in relation to minorities. In the Hungarian part, the Hungarians in proportion to the number of minorities in the political position were the dominant majority. Hungary had a short-lived policy of tolerance towards minorities. There, the minorities underwent the process of magy arization or assimilation. The government made an assimilating pressure against minorities in order to form a purely Hungarian state. In the Hungarian part the minorities were Slovaks, Ukrainians, Romanians, Serbs and Croats, Germans-Sasses minority. A number of the German minority lived in Hungary in a number of cities, who were called "Schwabs". ${ }^{2}$

The Austrian part of the Empire had a number of minorities. In this part of the Empire there was a small number of provinces that were inhabited by a mono-nationality. In the province of Bohemia, Moravia and Shlezia lived Czechs and Germans, while in Shlezia even the Polish. In the north of the Adriatic coast lived the Italians and Slovenians while in the south of it lived Italians and Croats.

In the province of Bukovina lived Ukrainians, Germans and Romanians ${ }^{1}$. During the XIX century the Austro-Hungarian Empire was inclined to make concessions to the minorities regarding the requirements to education in their mother tongue. The Austro-Hungarian Constitution of 1867 (Article 12) had foreseen the drafting of a "Law on Nationalities", which would provide the inalienable rights of each group to preserve its nationality and language. Similarly, the Austrian Constitution (Article 19) provided that all nationalities have the right to preserve and advance the national character and language. The Austrian laws foresaw the use of languages in education, administration and public life. ${ }^{4}$

In the province of Bukovina lived Ukrainians, Germans and Romanians ${ }^{1}$. During the XIX century the Austro-Hungarian Empire was inclined to make concessions to the minorities regarding the requirements to education in their mother tongue. The Austro-Hungarian Constitution of 1867 (Article 12) had foreseen the drafting of a "Law on Nationalities", which would provide the inalienable rights of each group to preserve its nationality and language. Similarly, the Austrian Constitution (Article 19) provided that all nationalities have the right to preserve and advance the national character and language. The Austrian laws foresaw the use of languages in education, administration and public life. ${ }^{4}$

The Ottoman rule in most of the Balkan Peninsula lasted five centuries. The Ottoman Empire until the first half of the XIX and XX centuries was a theocratic empire in which people were divided not on linguistic lines, but on religious affiliation. ${ }^{5}$ So, a criterion in determining the minorities was not the language, but the religion ${ }^{3}$. In the Ottoman Empire we have cases of intervention of the Great Powers in the protection of religious minorities. We should mention the famous Kuçuk-Kajnardzhiski Agreement of 1774, under which Russia wins the right to the protection of the Orthodox Christians in the Balkans ${ }^{6}$. Russia lost this right with the Peace of Paris of $1856 .{ }^{7}$

The XIX century found the Balkan peoples under the common roof of the Ottoman Empire, mixed in their vilay ets. Among these people resumed the process of national awakening, which was manifested by general movements: cultural, educational and military. The Ottoman Empire began to collapse under the strokes of national awakening and uprisings in the Balkans in the XIX and XX centuries. In the XIX century, the Balkan national movements reached their successes in the field. Gradually, vassal principalities were created, and later autonomous under the sovereignty of the Sultan up to the independent states. ${ }^{8}$ In 1821 explodes the Greek uprising against the Ottoman Rule. In this conflict, the Great Powers intervened such as England, France and Russia on the side of Greece. At the London Conference on February 3, 1830, the above mentioned powers sign the protocol whereby the independent Greek state is formed. ${ }^{9}$

\footnotetext{
${ }^{1}$ Sonila Boçi, Minoritetet në Shqipëri ndërmjet identitetit dhe integrimit 1939 -1949, Tiranë, 2012, fq. 23.

${ }^{2}$ V. Ortakovski, Minorities in the Balkan..., fq. 44,45. Dispozitat e Konferencës së Londrës u përforcuan në marrëveshjen e nënshkruar ndërmjet Fuqive të Mëdha dhe Greqisë në vitin 1863, me rastin e përfshirjes së ishujve jonianë, si dhe në Konventën e Konstantinopojës, më 24 maj 1881, me të cilën u ërtetua kufiri greko-osman, parashikonte dispozita për besimtarët my slimanë, të ciltë jetojnë në territorin që është vënë nën kontrollin grek. Shih më shumë: V. Ortakovski, Minorities in the Balkan..., fq. 55.
} 
Signatory powers under the Protocol of February 3, 1830 at the London Conference, a condition for acceptance of the independence of the state of Greece had foreseen the protection of religious minorities, who had remained in the new state, or "all entities in the new state, whatever their religion may be, will have access to all public services, functions, all to be treated equally, regardless of changes in religious beliefs in all relationships, civil or political". ${ }^{10}$ Before reaching of the Peace of Paris on 18.02.1856, the Sultan, under the influence of the Great Powers, declares the Hati-humujan Decree, whereby he is committed to provide complete freedom of all believers (Section VII), to allow free use of faith, language

(VIII), and all officials will be determined without taking into consideration the nationality or religion, given their skills (XIII). ${ }^{11}$

After the end of the Russian-Turkish War (1877-1878), along with the process of disintegration of the Ottoman Empire, continued the formation of new states in the Balkans. As a result of the decisions of the Berlin Congress on July 13,1878, in the Balkans we have a new reality. Under the Treaty of Berlin are made the following decisions: Serbia gains independence and territorial expansion to the city of Vranje; Montenegro gains state independence; Romania gains state independence; Bulgaria becomes autonomous with smaller dimensions than that of the Saint Stefan's Treaty, which was under the sovereignty of the Sultan. ${ }^{12}$

This process re-opened the issue of preconditions to protect minorities from the discrimination of these states. In the decisions of the Berlin Congress of 1878 articles were incorporated, which provided protection of religious freedom for minorities and equality of citizens in the countries that won autonomy and independence. The same provisions also were asked to be applied to peoples who had remained in the framework of the Ottoman Empire. Article 62 of the Treaty of Berlin obliged the Ottoman Empire to respect the principles of religious freedom, civil and political rights: "for carrying out of public services and different professions... no distinction shall be made in relation to religion, not even in court". ${ }^{13}$

The Berlin Agreement had given obligations even to the Balkan states that gained independence, or autonomy. The new Balkan states were imposed the protection of the minorities as a condition to gain independence. Article 35 of the agreement applied for Serbia: "In Serbia, religious differences cannot in any case serve as a ground for non-using of civil and political rights, the rights for public services... Freedoms and religious services will be provided for all citizens of Serbia, as well as to foreigners, nor there will be obstacles neither in the hierarchy of the organization of the religious community". ${ }^{14}$ Articles 39 and 40 of the Berlin Agreement provide that the Muslim inhabitants in the areas that belong to Serbia according to the agreement, have the right to stay or move to the Ottoman Empire. According to Article 34 and 35, inhabitants in Serbia and in Montenegro with the Ottoman origin, as well as all others, should enjoy all religious, civil and political rights. ${ }^{15}$

At the Berlin Congress the position of ethnic minorities was taken into consideration. Article 4 of the agreement with Bulgaria reads as follows: "the parts where Bulgarians are mixed with Turks, Romanians, Greeks and other populations, the rights and interests of these peoples should be considered in connection with laws and in organic law-making" 16

The Berlin Agreement marks an important step in the protection of minorities in relation to the Congress of Vienna and Paris Protocol of 1856. It should be noted that the Balkan countries, none of them even were conscious to ensure protection to minorities. However, the facts that in the agreement is mentioned and protected only religious minorities and not ethnic minorities, it means that we are dealing with a step backward.

\footnotetext{
${ }^{3}$ Po aty, fq. 46.

${ }^{4}$ Për më tepër, shiko: Vlladimir Ostrakovski, Minority in the Balkan, Skopje, 1998, fq. 47-49.

${ }^{5}$ Mehmet Hacisalihoglu and Fuat Aksu, A general Intruduction to Minority Issues in th Balkan, Istanbul, 2007, fq. 3,4

${ }^{6}$ Ilija Przić, Zaštita manjina, Beograd, 1933, fq. 32-35, Vrskiu i Jezički Manjina, fq. 25-26.

${ }^{7}$ Boris Krivokapić, Zaštita Manjina..., Knjiga 1, fq. 82.

${ }^{8}$ Eva Tafili (Hy skaj), Sfidat e nacionalizmit, Rasti i Ballkanit, Tiranë, 2008, fq. 68.

${ }^{9}$ Vlladimir Ostrakovski, Minorities in the Balkan, Skopje, 1998, fq.54.

${ }^{10}$ Fracesko Kaparoti, Prava Pripadnika Etnički..., fq. 28.
} 
The International Convention of 1881 between Germany, Austria-Hungary, France, England, Italy, Russia and the Ottoman Empire contains provisions on religious freedom and equality of Muslims who live in the territories returned to Greece (Article VIII). ${ }^{17}$

Very soon, the independent Balkan countries began to develop their nationalist platforms for a "greater country". In the name of "liberation of the non-liberated brothers", the Balkan countries such as Serbia, Greece, Bulgaria and Montenegro caused two Balkan wars in 1912-1913. ${ }^{18}$ The First Balkan War started in October 1912 between the Balkan Alliance and the Ottoman Empire. In fact, it was a war to divide the Ottoman territories among themselves, and in fact these territories used to be inhabited by the Albanians. During the First Balkan War, the countries that constituted the Balkan Alliance occupied a great part of the Albanian territories. The Serbian army invaded Kosovo, the Albanian area of the Presevo Valley, the one in today's Macedonia; the Montenegrin army besieged Shkodra, while the Greek army took most of Çamëria and Janina. Under these circumstances, a situation was created not only difficult, but also dangerous to the Albanians and minority groups in the Balkan countries. The occupation of the Albanian lands and other parts of the Balkans by the Balkan states were "vindicated" by the decisions of the Conference of Ambassadors in London in 1913. Balkan countries such as Serbia, Greece and Montenegro undertook wild campaigns to change the ethnic structure, not excluding the mass killings, expulsions from territories that had occupied during the First Balkan War.

After the First World War, the Balkan map changed. Alongside the existing states in December 1918 was created the Serb-Croat-Slovene Kingdom, incorporating within itself a part of the territory that once was part of the Austro-Hungarian Empire and the territories which were recognized by the decisions of the London Conference (1913). The Balkan countries signed a peace accord with the winning countries. A special topic was the issue of the minority protection. It should be noted that the Versailles System had raised certain categories of agreements on the protection of minorities and consequently the Balkan countries were not included in the same category of the accords concerning this problem. Out of five groups of treaties which had provisions or special chapters on the protection of minorities, as they are in total, the Balkan countries were part of the first four groups. Down below we present the Balkan states, part of the treaties groups:

- Peace agreements in which were inserted special chapters on the protection of minorities in Bulgaria (Neuilly sur Seine, 27 November 1919);

- Special agreements for the protection of minorities, which constituted the first group of the international instruments containing provisions for the protection of minorities, which would be guaranteed by the League of Nations and the Kingdom of Serbs-CroatiansSlovenians (St. Germain, 10 September 1919); Romania (Paris, 9 December 1919); and Greece (Sevres, 10 August 1920);

- Declarations on the protection of minorities with Albania (October 2, 1921);

Other international agreements on the protection of minorities - in the period between the Two World Wars two agreements at bilateral level were completed, which addressed various aspects of the problems of minorities (such as bilateral agreements between Yugoslavia and Italy, the Rapal's 1920, of Rijeka 1924), including here the exchange of the population (such as the agreements on the exchange of the population between Greece and Bulgaria in 1919, Greece and Turkey in 1923, and Bulgaria and Romania in 1940).

The first of such agreements is the Convention between Greece and Bulgaria for the mutual exchange, signed in Nei on 27 September 1919.

${ }^{11}$ Ilija Przič, Novo medjunarodno pravo..., fq. 78.

${ }^{12}$ Vlladimir Ostrakovski, Minorities in the Balkan, fq. 57-59.

${ }^{13}$ Po aty, fq. 62

${ }^{14}$ Patrick Thornbery, International Law and the Rights of Minorities, Oxford, 1991, fq. 31.

${ }^{15}$ Vlladimir Ostrakovski, Minorities in the Balkan, Skopje, fq. 62.

${ }^{16}$ M. STojković, Balkanski ugovorni odnosni (1876-1996), Beograd, 1998, tom I, fq. 119.

${ }^{17}$ Fracesko Kaparoti, Prava..., fq. 30.

${ }^{18}$ Noel Malcom, KOSOVA - një histori e shkurtër, Tiranë, 2001, fq. 263-265; George Castelan, Histori e Ballkanit, Prishtinë, 1998, fq. 394; Sonila Boçi, Minoritetet në Shqipëri ndërmjet identitetit dhe integrimit 1939 -1949, Tiranë, 2012, fq. 30. 
The Contracting States agreed that its citizens, members of ethnic minorities, religious, linguistic, can move freely to the territory of the other contracting state and at the same time were obliged to facilitate the movement. ${ }^{19}$ The Greek-Bulgarian agreement contained 16 articles, which envisaged the exchange of the population to be done under defined conditions.

Article 4 states that rights to voluntary migration have all persons aged over 18 years. Article 5 stipulates that the immigrant loses his citizenship when gives up and is granted with the citizenship of the other country. Pursuant to Articles 8 and 9 The Joint Commission was authorized to pay the immovable property. Article 13 stipulated that the costs of the Commission were to be covered by the two governments. ${ }^{20}$ Otherwise, the contents contains Conventions on the exchange of population between Greece and Turkey, signed in Lausanne on January 30, 1923. Article 1 provides that such members can live in Turkey and Greece. From the Agreement on the Exchange of the Population were excluded Greek residents in Istanbul and Turks in western Thrace (Article 2). Article 7 provides that immigrants, who do not obtain the citizenship of the country where they go, are entitled the right to obtain the citizenship that they had before migration. Article 8 provides the pay ment of immovable property. ${ }^{21}$ Under the agreement for exchange between Greece and Turkey, even 2.000.000 million people were exchanged (about 400,000 Turks and 1.300000 to 1.500000 million Greeks). ${ }^{22}$ It should be noted that the respective countries used the opportunity to clear its territory from members of other minorities. The Greek government took the opportunity of the population exchange with Turkey and in this way tried to involve the Muslims of Epirus, i.e. the Albanian minority in the process of exchange of the population, provided by the provisions of the Treaty of Lausanne, i.e. the Albanian minority that lived in the region of Çamëria. ${ }^{23}$ The problem of exchanging of the Muslim Albanians was laid out at the Conference of Lausanne even by the Italian representative and all agreed that Albanians should remain outside of this process. ${ }^{24}$ However, during 1925-1926 the issue of eviction and maltreatment of the Çams was also raised in the Council of the League of Nations. It was estimated that until 1925 from Greece were moved 5,000 Muslim Albanians. ${ }^{25}$ A subject on the population exchange was the agreement between Bulgaria and Romania, reached on 09.07.1940.

The Contracting Parties agreed that the exchange of the population is done within a year. ${ }^{26}$ No doubt in this category is included the agreement between Yugoslavia and Turkey, signed in Ankara in the summer of 1938 in which was foreseen the displacement of hundreds of "Muslims" from the Yugoslav Kingdom to Turkey. The real purpose of this agreement was the displacement of Albanians to Turkey. The issue of regulating the minority rights after World War Two has been treated only at regional level, bilateral, multilateral, but not at the universal one. Of the multilateral level is the Memorandum of Conciliation between Italy, UK, USA on one side, and Yugoslavia on the other side, achieved in 1954, whereby has been regulated the protection of minorities on both sides of the border in Trieste free zone. This agreement in paragraph 1 refers to the principles of the Universal Declaration of the Human Rights, strengthens the equal rights of minorities, and confirms the special rights of minorities. ${ }^{27}$ With the Osjek Agreement of 1975 about the borders between the Socialist Federal Republic of Yugoslavia and Italy, even though the effect of the 1954 agreement was completed (special statute for minorities). ${ }^{28}$

${ }^{19}$ Boris Krivokapić, Zaštita Manjina u medjunarodnom..., Knjiga 1, fq. 115

${ }^{20} \mathrm{Për}$ më tepër mbi përmbajtjen e Konventës, shiko: Ilija Przić, Tumačenje grčko-bugarske konvencije o uzajmom iseljavanju, u Novu medjunarodno pravo, fq. 136-140

${ }^{21}$ Për më tepër për përmbajtjen e Konvetnës, shiko: Konvecija izmedju Grčke i Turske o razmeni Grčkog i Turskog Stanovništva 1923: Boris Krivokapić, Zaštita Manjina u medjunarodnom..., Knjiga 1, fq. 500-503

${ }^{22}$ Boris Krivokapić, Zaštita Manjina u medjunarodnom... Knjiga 1, fq. 116

${ }^{23}$ Shiko më shumë:Prof. Dr. Paskal Milo, Politika e Jashtme e Shqipërisë, Tiranë, 2013, fq. 588-599

${ }^{24}$ Beqir Meta, Tensionet greko-shqiptare 1939-49, Tiranë, 2002, fq. 135

${ }^{25}$ Areb Puto, Shqipëria Politike 1912-1939, Tiranë, 2009, fq. 340

${ }^{26}$ Për më tepër, shiko: Boris Krivokapić, Zaštita Manjina u medjunarodnom... Knjiga 1, fq. 116, 117.

${ }^{27}$ Specijalni statut o manjinama uz Memorandum o saglasnosti izmedju Italije, Ujedijenog Kraljestva, SAD i Jugoslavije (1954): Boris Krivokapić, Zaštita Manjina u medjunarodnom..., Knjiga 1, fq. 543

${ }^{28}$ Ugovor izmedju SFR Jugoslavije i Italije (Osimski sporazum 1975): Boris Krivokapić, Zaštita Manjina u medjunarodnom... Knjiga 1, fq. 545 
During the Yugoslav crisis in the 90's, the international community set conditions to the states that had declared independence. According to "Carrington Plan", the member states of the community agree to recognize the independence of all Yugoslav republics if they accept to be subject to certain conditions. Among the conditions for recognition of statehood was the acceptance of the provisions set out by "Carrington Plan" of the Chapter II, having to do with human rights and national or ethnic groups. ${ }^{30}$

London Conference (1992) - formed the Working Group on Ethnic and National Communities and Minorities and the Special Group for Kosovo. The ethnic communities sent their representatives, but they had bilateral talks with the international staff of the working group. ${ }^{31}$

In the aforementioned period in this field were concluded many agreements, which had to do with the human rights or the protection of minorities. Such agreements reached Hungary with Ukraine, with Slovakia, with Slovenia, with Romania, with Croatia, etc. Bilateral agreements have concluded Bulgaria, Albania, Romania, Croatia, Slovenia, etc.

Today a special attention is paid to the issues of minority protection. With the problem of the minority position are dealing various entities (such as states, international organizations, multilateral and bilateral organizations), especially dealing with different international documents (agreement as well as the provisions of the Domestic Law (constitutional provisions, special laws, etc.). The growing interest for the position of the minorities comes as a result of the increasing number of minorities, rising of nationalism and chauvinism, strengthening the idea of the need for the protection of human rights, assessment that without arranging the problems of minorities there cannot be international stability, etc

Table 2: Balkan states according to the number of minorities

\begin{tabular}{|l|l|}
\hline Minorities & States \\
\hline Up to $10 \%$ & Albania, Greece, Croatia, Kosovo \\
\hline $10-20 \%$ & Bulgaria, Romania, Serbia \\
\hline $30-40 \%$ & Macedonia, Montenegro \\
\hline $\begin{array}{l}\text { Multinational } \\
\text { states }\end{array}$ & Bosnia \& Herzegovina \\
\hline
\end{tabular}

Source: Boris Krivokapić, Protection of minorities in the international... Book 1, p. 30; Census result of 2011 in Kosovo.

${ }^{29}$ Boris Krivokapić, Zaštita Manjina u medjunarodnom..., Knjiga 1, fq. 178

${ }^{30}$ Marc Weller, Shtetësia e kontestuar, Prishtinë, 2011, fq. 99, 100.

${ }^{31}$ Geert - Hinrich AHRENS, Diplomacia mbi tehun e thikës, Pengimi i konfliktit etnik dhe Grupi i Punës për Minoritetet i Konferencave për Jugosllavinë, Tiranë, 2010, fq. 72. 
Table 3. Ethnic, language and religion structure of the Balkan states:

\begin{tabular}{|c|c|c|c|}
\hline State & Ethnic groups & $\begin{array}{c}\text { Official } \\
\text { language }\end{array}$ & Religions \\
\hline Albania & $\begin{array}{l}\text { Albanians } 83 \%, \quad \text { Greeks } \\
0.87 \% \text {, Macedonians } \\
0,20 \% \text {, } \\
\text { Montenegrins } 0,01 \% \text {, etc. }\end{array}$ & Albanian & $\begin{array}{l}\text { Is lamic } 58 \% \\
\text { Orthodox } 6,75 \% \\
\text { Catholic } 10 \% \\
\end{array}$ \\
\hline $\begin{array}{l}\text { Bosnia- } \\
\text { Herzegovina }\end{array}$ & $\begin{array}{l}\text { Bosnians } 48 \% \text {, Serbs } 32 \% \text {, } \\
\text { Croatians } 15 \% \text {, others } 5 \%\end{array}$ & $\begin{array}{l}\text { Bosnian, } \\
\text { Serbian, } \\
\text { Croatian }\end{array}$ & $\begin{array}{l}\text { Is lamic } 48 \% \\
\text { Orthodox } 32 \% \\
\text { Catholic } 15 \% \\
\end{array}$ \\
\hline Bulgaria & $\begin{array}{l}\text { Bulgarians } 85 \% \text {, Turks } 8 \% \text {, } \\
\text { Romas } 2 \%\end{array}$ & Bulgarian & $\begin{array}{l}\text { Orthodox } 85 \%, \\
\text { Islamic } 13 \%\end{array}$ \\
\hline Greece & Greeks $98 \%$ & Greek & Orthodox $98 \%$ \\
\hline Croatia & 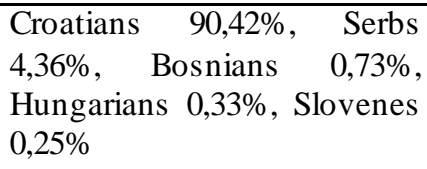 & Croatian & $\begin{array}{l}\text { Catholic } 86,28 \% \\
\text { Orthodox } 4,44 \% \\
\text { Islamic } 1,47 \%\end{array}$ \\
\hline Montenegro & $\begin{array}{l}\text { Montenegrins } 41 \%, \quad \text { Serbs } \\
30 \%, \quad \text { Bosnians } \\
\text { Albanians } 6 \% \text {, Croatians } 1 \%\end{array}$ & Montenegrin & $\begin{array}{l}\text { Orthodox } \\
\text { Moslem } \\
\text { Catholic }\end{array}$ \\
\hline Macedonia & $\begin{array}{l}\text { Macedonians } 65 \% \text {, Albanians } \\
\text { over } 25 \% \text {, Turks } 4 \% \text {, Romas } \\
3 \%\end{array}$ & Macedonian & $\begin{array}{l}\text { Orthodox } 67 \% \\
\text { Moslem } 30 \%\end{array}$ \\
\hline Romania & $\begin{array}{l}\text { Romanians } 89 \% \text {, Hungarians } \\
9 \% \text {, Serbs, Germans, } \\
\text { Ukrainians, Russians, Romas } \\
2 \%\end{array}$ & Romanian & $\begin{array}{l}\text { Orthodox } 70 \% \\
\text { Catholic } 6 \% \\
\text { Protestant } 6 \%\end{array}$ \\
\hline Serbia & $\begin{array}{l}\text { Serbs } 83 \%, \quad \text { Hungarians } \\
3,53 \%, \quad \text { Romas } 2,05 \%, \\
\text { Bosnians 2,02\%, Croatians } \\
0,81 \% \text {, Albanians }{ }^{32} \text { ? }\end{array}$ & Serbian & $\begin{array}{l}\text { Orthodox } 84,59 \% \\
\text { Catholic } 4.97 \% \\
\text { Moslem } 3,10 \% \\
\text { Protestant } 0,99 \% \\
\end{array}$ \\
\hline Kosovo & $\begin{array}{l}\text { Albanians } 92,9 \%, \\
1,5 \% \text {, Bosnians } 1,6 \% \text {, Turks } \\
1,1 \% \text {, Romas } 0,5 \% \text {, others } \\
2,3 \%\end{array}$ & $\begin{array}{l}\text { Albanian } \\
\text { Serbian }\end{array}$ & $\begin{array}{l}\text { Moslem 96,0\% } \\
\text { Orthodox } \\
\text { Catholic }\end{array}$ \\
\hline
\end{tabular}

Source: INSTAT, Census of population and housing; Boris Krivokapić, Protection of minorities in the international... Book1, p. 33;

The population census in Montenegro 2003; The population census in Serbia, 2011; Census in Croatia, 2011; Result of the Census in Kosovo 2011.

In the case of Albania, 13\% of respondents prefer not to be declared in relation to ethnic and religious affiliation.

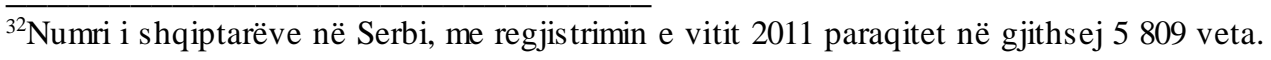


In Table No. 3 is clearly seen that according to the religious view, the state with the largest number of Muslim believers is Kosovo and Albania. Croatia is the only state in the Balkans with the Catholic majority. The state which constitutes the largest number of orthodox is Greece with $98 \%$, followed by Bulgaria and Serbia.

States that have two or more official languages are Kosovo and Bosnia and Herzegovina. Taking into consideration the large number of Albanians in Macedonia, certainly the Albanian language should be the official language at the republic level.

\section{Bibliography and Sources}

1. AHRENS,Geert - Hinrich, Diplomacia mbi tehun e thikës, Pengimi i konfliktit etnik dhe Grupi i Punës për Minoritetet i Konferencave për Jugosllavinë, Tiranë, 2010.

2. Boçi, Sonila, Minoritetet në Shqipëri ndërmjet identitetit dhe integrimit 1939 -1949, Tiranë, 2012.

3. Hacisalihoglu, Mehmet and Fuat Aksu, A general Intruduction to Minority Issues in the Balkan, Istanbul, 2007.

4. Kaparoti, Fracesko, Prava Pripadnika Etnički, Verskih i iezikčki manjina, Beograd, 2001.

5. Krivokapić, Boris, Zaštita Manjina u medjunarodnom i uporednom pravu, Knjiga 1, Novi Sad, 2004.

6. Malcom,Noel, KOSOSVA - një histori e shkurtër, Tiranë, 2001.

7. Meta, Beqir, Tensionet greko-shqiptare 1939-49, Tiranë, 2002.

8. Milo, Paskal, Politika e Jashtme e Shqipërisë, Tiranë, 2013.

9. Ostrakovski, Vlladimir Minority in the Balkan, Skopje, 1998.

10. Przić, Ilija, Zaštita manjina, Beograd, 1933.

11. Przič,Ilija Novo medjunarodno pravo, Beograd, 1934.

12. Puto,Arben, Shqipëria Politike 1912-1939, Tiranë, 2009.

13. Tafili, Eva (Hyskaj), Sfidat e nacionalizmit, Rasti i Ballkanit, Tiranë, 2008.

14. Thornbery, Patrick, International Law and the Rights of Minorities, Oxford, 1991.

15. Weller, Marc, Shtetësia e kontestuar, Prishtinë, 2011.

\section{Sources:}

1. INSTAT, Censusi i Popullsisë dhe i banesave.

2. Popis stanovništva u Crnoj Gori 2003.

3. Popis stanovništva u Hrvatskoj 2011.

4. Popis stanovništva u Srbiji 2011.

5. Rezultati i regjistrimt në Kosovë 2011. 